Chapter 19

\title{
Case study Oberschwaben / Allgäu / Vorarlberg / Prättigau - Risk Assessment of Abiotic and Biotic Hazards
}

\author{
Holger Veit, Holger Grieß, Bernhard Maier and \\ Peter Brang
}

Additional information is available at the end of the chapter

http://dx.doi.org/10.5772/56284

\section{Introduction}

\subsection{The present condition}

The transnational case study of the MANFRED Project includes regions of southern Germany, western Austria and eastern Switzerland (Oberschwaben / Allgäu / Montafon / Prättigau) and is represented by the forest administrative district of Ravensburg in Baden-Württemberg, the forest administration unit of Kempten in Bavaria, the mountain forest enterprise Stand Montafon in the Montafon Valley of Vorarlberg and the region of Prättigau as a part of Grisons (see figure 1). According to the encompassed landscapes it comprises a wide range of forest management aspects.

Timber production is carried out throughout the whole case study area from the lower foothills on the border of Lake Constance up to the steep regions of high the mountain ranges where Norway spruce (Picea abies (L.) Karst.) is by far the most abundant tree species. In the past violent storm events and bark beetle mass outbreaks have raised forest management problems [1] especially for secondary growth forests dominated by Norway spruce in the test areas of Ravensburg and Kempten. Particularly in the Montafon valley the protection of human settlements and traffic infrastructure from rock fall and landslides is the most important forest function $[2,3]$.

Within this case study information on management practices dealing with protection forest issues has been exchanged and discussed with stakeholders for advice and colleagues from German speaking countries to be able to cope with the challenges of climate change and 


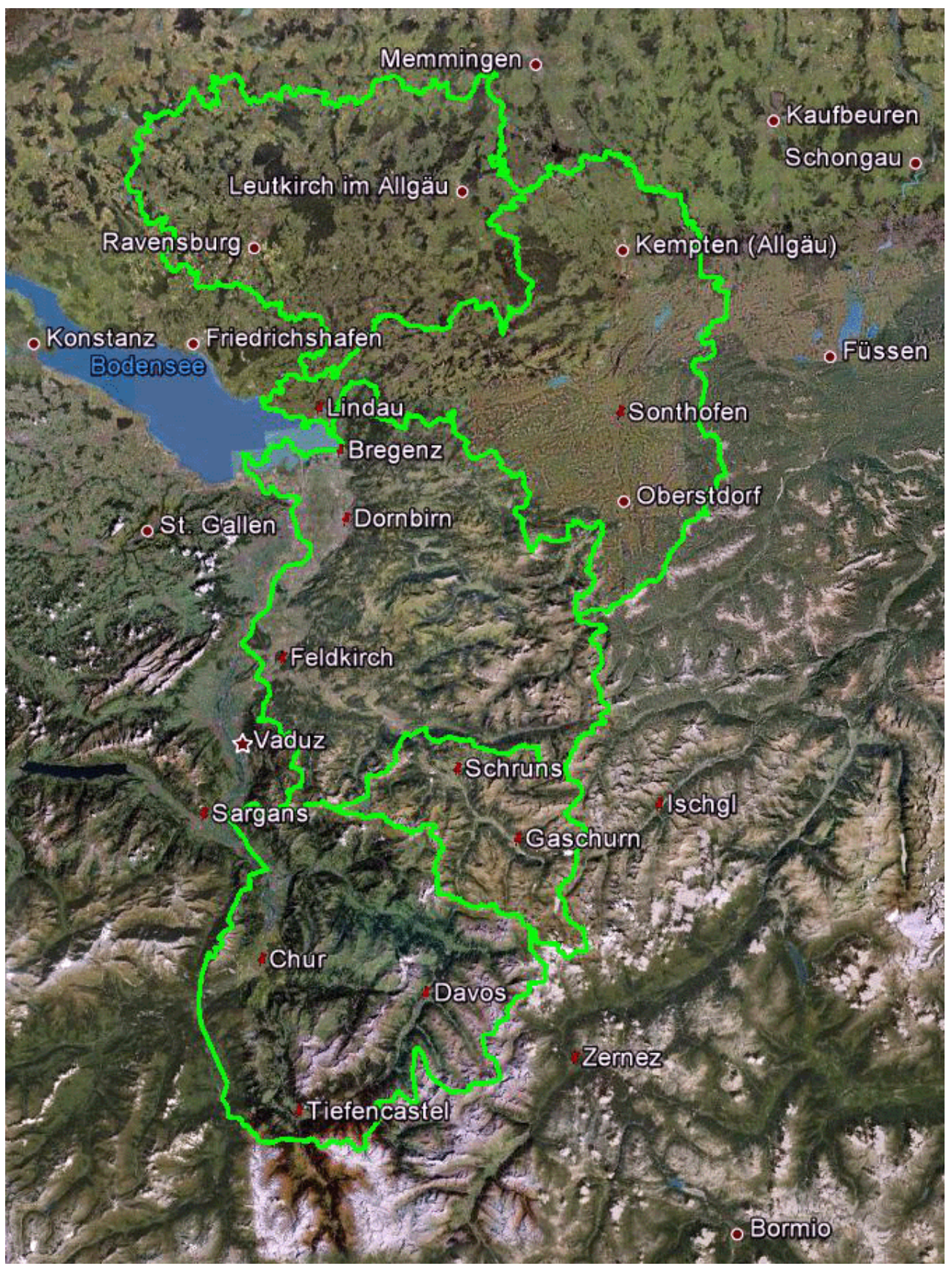

Figure 1. The case study Oberschwaben / Allgäu / Montafon / Prättigau in the cross border region of Germany, Austria and Switzerland (North-South $~ 150 \mathrm{~km}$, West-East $\sim 55 \mathrm{~km}$ ) 
address existing knowledge gaps. Know-how and specific already made up guidelines were shared through training courses and made available for professional practitioners, decision makers and scientists.

\section{Oberschwaben / Ravensburg}

\subsection{Geographical setting}

Ravensburg is a district in the far south-east of Baden-Württemberg, Germany. Neighbouring districts are Bodensee, Sigmaringen and Biberach, the Bavarian urban district Memmingen and the districts Unterallgäu, Oberallgäu and Lindau. The landscape in the district are the hills of Upper Swabia which rise from 458 metres above sea level in the valley of the river Danube to a maximum of 833 metres above sea level in the south-west and drop again to 395 meters above sea level at Lake Constance (figure 2). Upper Swabia is a region in Germany in the federal states of Baden-Württemberg and Bavaria. The name refers to the area between the Swabian Jura, Lake Constance and the Lech. It is situated in the central south of Germany consisting of the south-east of Baden-Württemberg and the south-west Bavarian Swabia region and is part of the Iller-Lech-Plateau, also known as the Upper Swabian Plain. Its landscape was formed by retreating glaciers after the Riss glaciations, leaving behind a large number of shallows which quickly filled up with water. This led to the large quantity of lakes in the area. The European watershed also passes through the region, with some rivers draining into the river Danube (ultimately flowing into the Black Sea) and others emptying into Lake Constance (ultimately ending in the North Sea).

\subsection{Climate}

The climate of the Ravensburg district and the Upper Swabian region as a whole is strongly influenced by the alpine range and Lake Constance expanding for $500 \mathrm{~km}^{2}$ on the borders of Germany, Switzerland and Austria. Temperatures are balanced due to this tremendous water reservoir. Mean annual temperature is $9.1^{\circ} \mathrm{C}$ and annual precipitation sums up to $1000 \mathrm{~mm}$. Winter frost periods are normally diluted unless the lake freezes itself. Especially in autumn and winter foggy periods may last for several weeks at a stretch. Resembling the weather regimes of other pre alpine foothills foehn winds are well known to speed up to gale force.

\subsection{Forest types, function and distribution}

Most of the forest in the district ( 48000 ha) is owned privately (67\%), whereas the state of BadenWürttemberg is in charge of $23 \%$ of the area. Another $10 \%$, to a lower extent by local municipalities and private forest enterprises. The Altdorfer Wald which is the largest coherent forest of Upper Swabia with a size $82 \mathrm{~km}^{2}$, is situated in the district of Ravensburg. Its elevation ranges from $450 \mathrm{~m}$ in the Schussen valley to $776,6 \mathrm{~m}$ a. s. 1 . in the southern part of the ridge. 


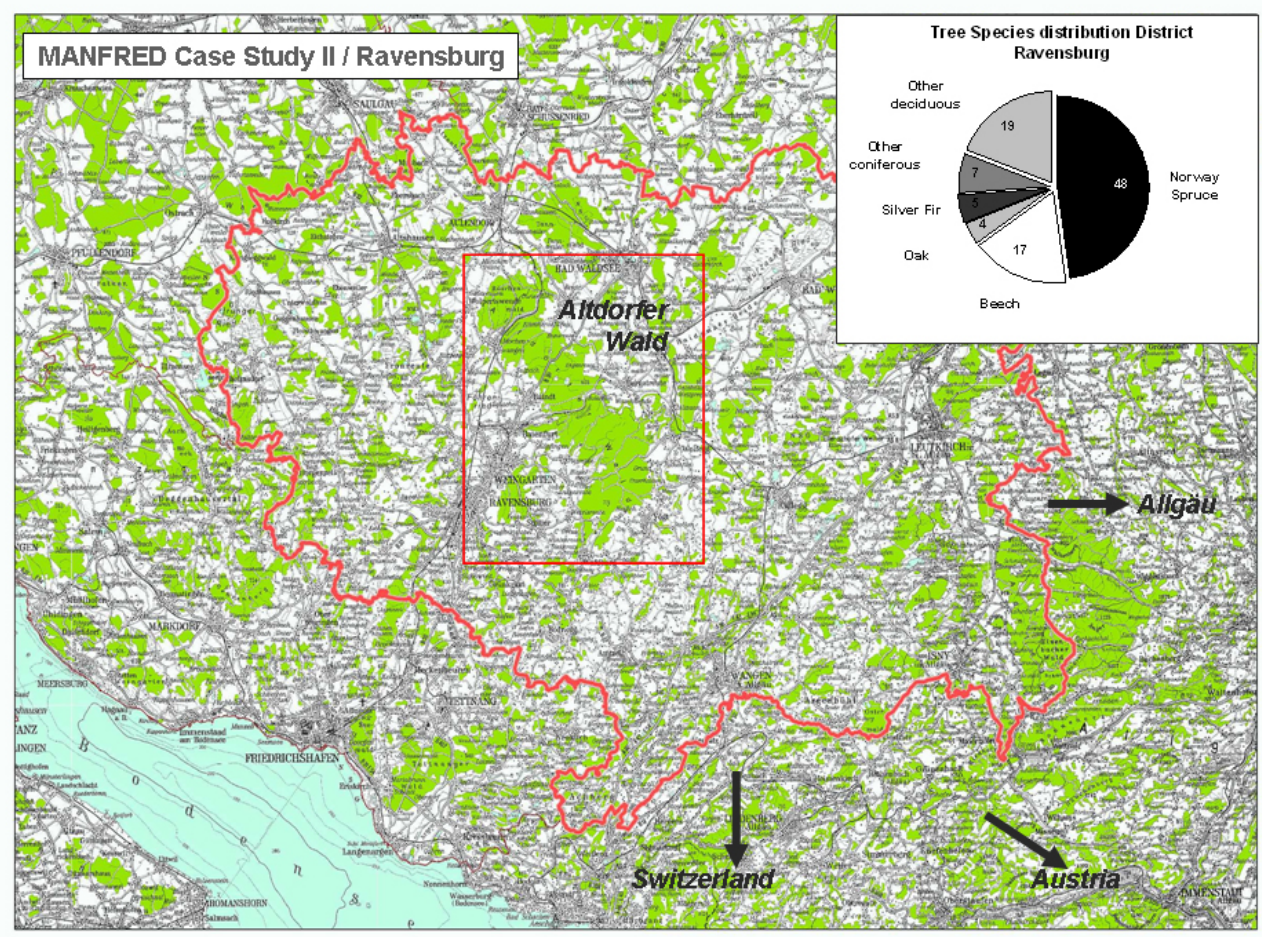

Figure 2. Case study subarea Ravensburg and tree species distribution

Mixed and pure Norway Spruce forests dominate throughout the district whereas European Beech and other deciduous tree species play a minor role. Forests are interspersed with bogs and a few open grasslands. Besides management of water protection and nature conservation areas half a million cubic meters of timber are sustainably harvested every year providing valuable resources for the regional sawmill, paper and plywood industry. Unfortunately many of the even aged Norway spruce dominated forests have been subject to wind throw and following bark beetle mass outbreak events in the past [1]. According to current climate projections there is a strong need for alternative silvicultural management options to preserve their growth and economical productivity.

\section{Allgäu / Kempten}

\subsection{Geographical setting}

The case study area Allgäu / Kempten (figure 3) is located in the south-western part of Bavaria ( $47.27^{\circ}$ and $47.864^{\circ}$ latitude and $9.563^{\circ}$ and $10.513^{\circ}$ longitude) between the foothills of the Alps close to Kempten and Füssen in the north and the high Alps in the south bordering the frontier 
to Austria. It includes the administrative districts Lindau in the West and Oberallgäu in the East. Altitudes range from 400m on Lake Constance up to the $2649 \mathrm{~m}$ high alpine summit of Hochfrottspitze.

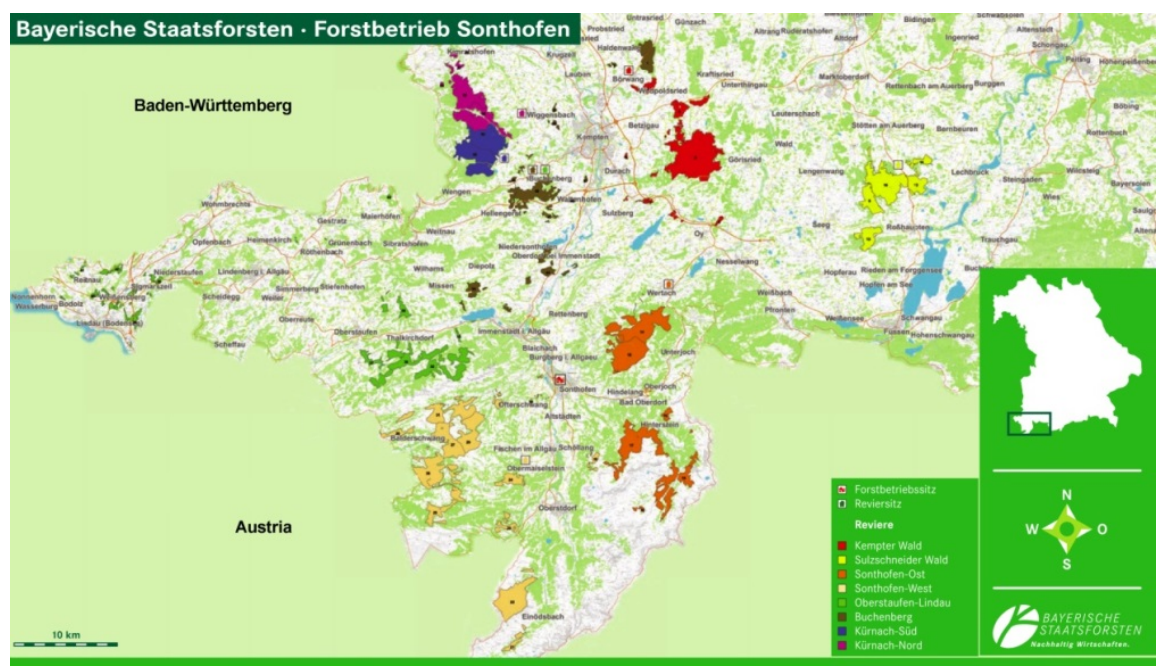

Figure 3. The case study area Allgäu / Kempten, Forest Management unit Sonthofen (BaySF)

The administrative district of Lindau is separated in 18 municipalities with approx. 76.000 inhabitants and a total area of 32.330 ha. The administrative district of Oberallgäu is the southernmost administrative district of the Federal Republic of Germany with an area of $1.527,55 \mathrm{~km}^{2}$ and approximately 150.000 inhabitants. Oberallgäu is separated in 28 municipalities.

\subsection{Climate}

In the western lowlands (400 - $500 \mathrm{~m}$ a.s.l.) along Lake Constance, annual temperatures average around $8-9^{\circ} \mathrm{C}$. In the Western Allgäu Uplands (500 - $700 \mathrm{~m}$ a.s.l.) the temperature mean is 7 $-8^{\circ} \mathrm{C}$. In both areas mean annual precipitation is $1.400-1.600 \mathrm{~mm}$. Within the administrative district of Oberallgäu mean annual temperatures range from $6.6^{\circ} \mathrm{C}$ in the northern parts to $5.8^{\circ} \mathrm{C}$ in the south. The mean annual precipitation in northern areas sums up to $1.000-1.800$ $\mathrm{mm}$ per year whereas the south receives $1.700-2.400 \mathrm{~mm}$ annually.

\subsection{Forest functions}

The case study area comprises 18.000 ha of forests of which about a third (5.500 ha) are declared protection forests securing settlements and infrastructural facilities from avalanches, rockfall, landslides and flooding. They develop under geologic conditions characterized by limestone, flysch and tertiaries with sandy clayey soil or bogs. Besides their essential protective function, 
forests are crucial for tourism and recreation activities (200 km of pedestrian walkways, 100 $\mathrm{km}$ of bicycle tracks) as well as for landscape and nature conservation.

\subsection{Forest types and distribution}

The most common tree species are Norway Spruce (Picea abies (L.) Karst.) (68\%), European Beech (Fagus sylvatica L.) and Silver Fir (Abies alba Mill.). They represent the climax species of typical mixed mountain forests in southern Germany (figure 4). Besides, forests stands also include Common maple (Acer campestre L.), Elm (Ulmus campestris L.), Ash (Fraxinus excelsior L.) and European mountain ash (Sorbus aucuparia L.) on a small scale.

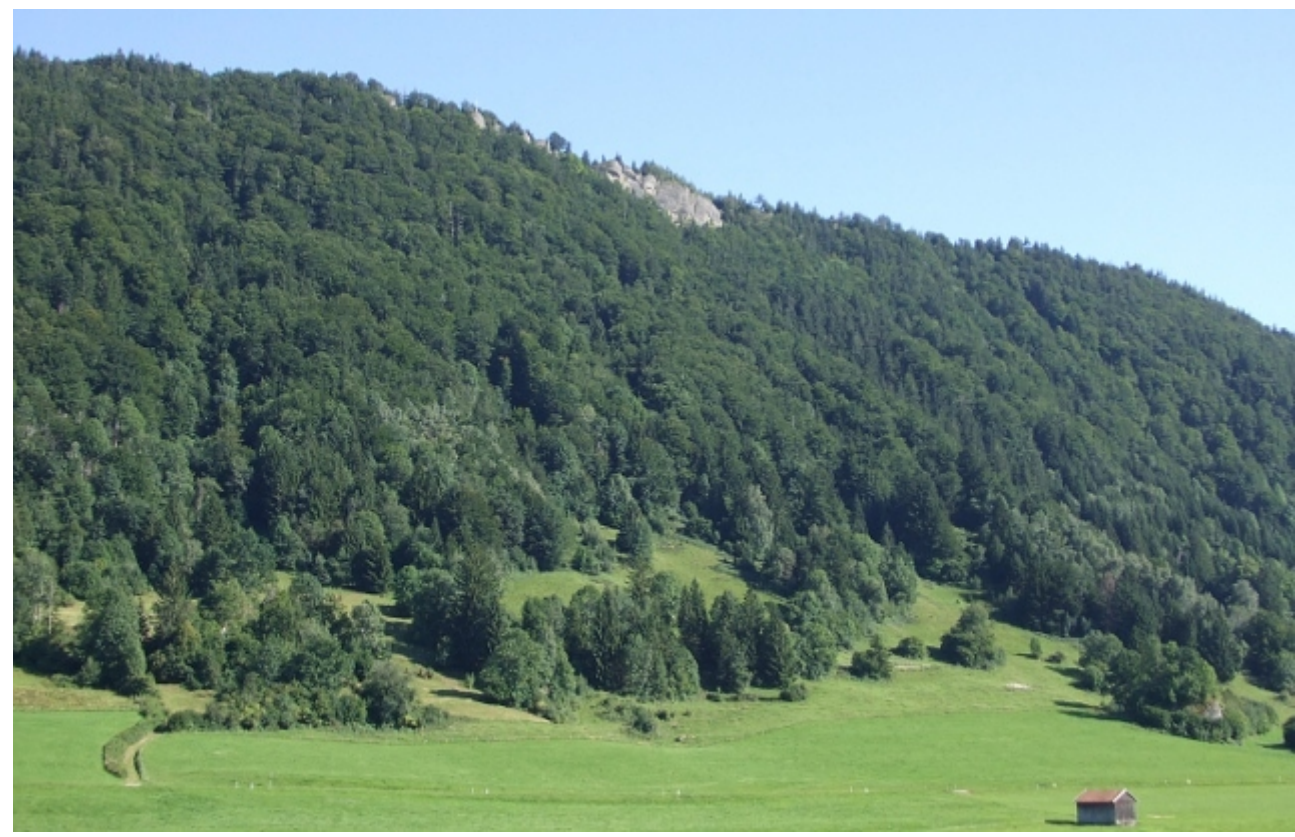

Figure 4. Mixed Forest on molasses conglomerate at Rottachberg in Upper Allgäu

The abundance of European Beech decreases with increasing altitude. Norway Spruces and Silver Firs take their place (Galio-Abietum and Homogyne-Piceetum). Above $1200 \mathrm{~m}$ a. s. 1. spruce forests (Honogyne-Piceetum, Asplenio-Piceetum and Adenostyloglabrae-Piceetum) naturally dominate the vegetation. Above $1400 \mathrm{~m}$ a. s. 1. single firs and beeches are able to survive and eventually only spruces cope with the climatic conditions of the high mountainous areas. From $1600 \mathrm{~m}$ a.s. 1. on only knee timber and Green alders (Alnus viridis L.) are growing. These species are crucial for the function of protection forests. 


\section{Vorarlberg / Montafon}

\subsection{Geographical setting}

The Montafon is a $39 \mathrm{~km}$ long valley located in the southern part of the Vorarlberg province, the westernmost federal state of Austria (see Figure 5). It extends from the mountain ranges of Rätikon and Silvretta peaking in the $3312 \mathrm{~m}$ high Piz Buin in the South and the Verwall mountains in the North. It stretches from the district capital of Bludenz in the West to the Bielerhöhe in the East which is the water divide of the Rhenish and Danubian stream systems and connects the Montafon to the Paznaun valley in Tyrol. The river Ill drains water from the mountain ranges to the river Rhine. The Valley hosts 10 municipalities associated in the administrative collectivity of the Stand Montafon. Forestry, Tourism and Hydropower serve as the backbone of local economy.

\subsection{Climate}

The Montafon is characterized by transitional climatic elements from the sub continental dry inner alpine valleys to the more cool humid areas of the alpine rims. Precipitation ranges from below $1000 \mathrm{~mm}$ to more than $1900 \mathrm{~mm}$ with a distinct summer maximum. Winters are snowy and milder than adjacent alpine areas to the East and South. Maximum annual temperatures range from about 5 to $13.3^{\circ} \mathrm{C}$ on the valley floor. Minimum temperatures are between -2.0 and $3.7^{\circ} \mathrm{C}$. Foehn winds are quite abundant in the Montafon.

\subsection{Forest functions}

The Stand Montafon Forstfonds is an alpine forestry enterprise that administers and manages about $70 \%$ of the forested area ( 8400 hectares).The forests predominantly grow on steep terrain at $1200 \mathrm{~m}$ above sea level and higher where $90 \%$ of all the forests have a protective function (figure 5). They offer essential protection against avalanches and landslides to the villages and infrastructural facilities in the valley. The most important objectives are the maintenance of the forests safeguarding the inhabited areas of the valley floor and ensuring the expected forest functionalities by managing them in a multifunctional sustainable way. Consequently the Stand Montafon is specialized in mountain forest silviculture. Harvesting is frequently carried out by means of cable cranes, in order to protect forest soil and remaining trees. Besides the essential protective function, forests in the valley do also serve for timber production and play an important role in tourism and recreation as well as landscape and nature conservation [2]. Very often management decisions consider various aspects of forest functions and need support by up-to-date and site-related silvicultural methods. Therefore the Stand Montafon has been cooperating with different Austrian, Swiss and Dutch research institutes in order to investigate certain aspects of the forests and to evaluate existing forest management techniques.

Due to the high elevation of the Stands forest property about $96 \%$ of the Montafon valley is naturally dominated by Norway Spruce (Picea abies (L.) Karst.), complemented by 3\% Silver Fir (Abies alba Mill.). The remainder of species are European Beech, Scots Pine and European Larch and further Maple, Mountain ash and Swiss stone pine. 


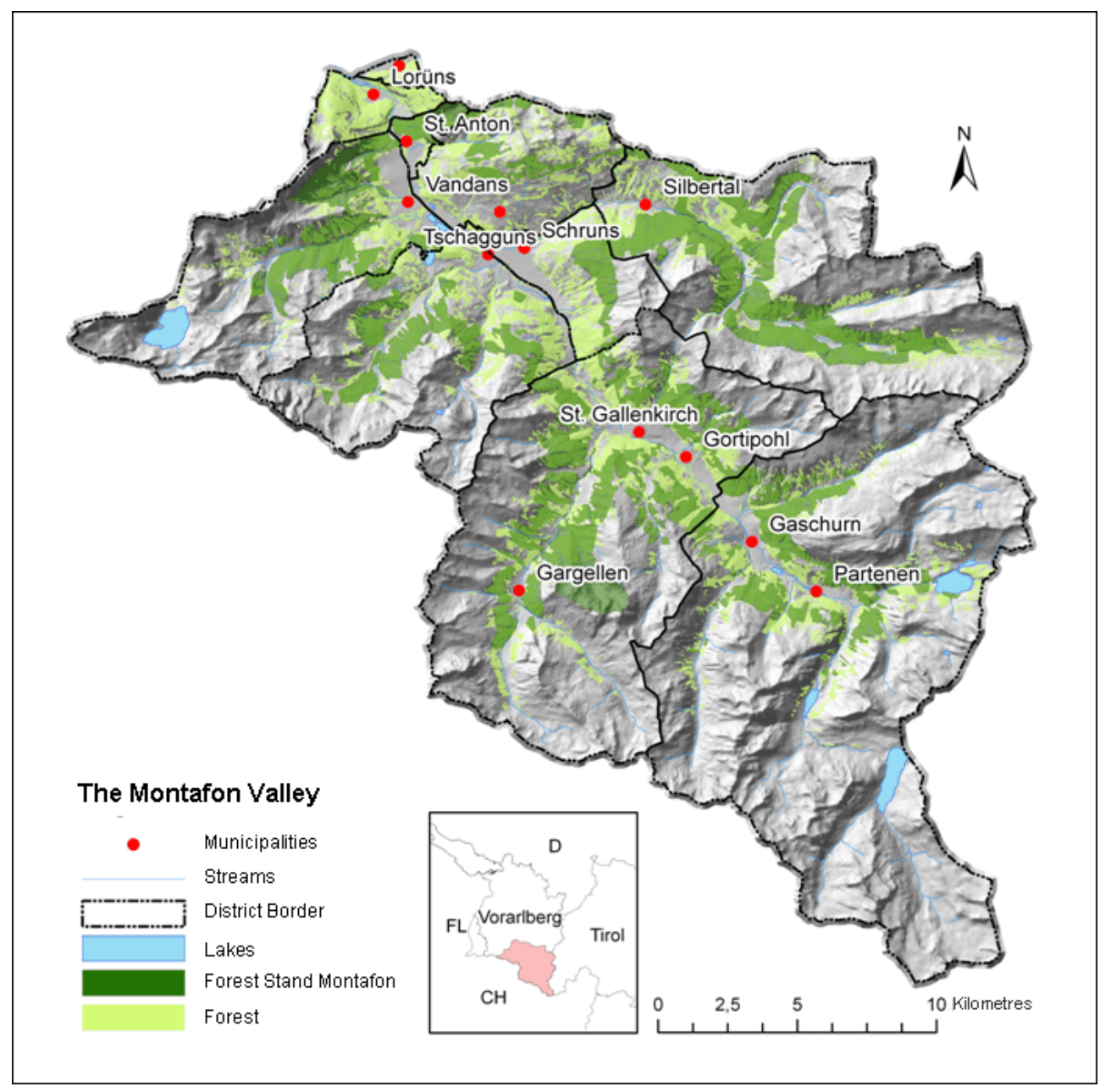

Figure 5. Stand Montafon, forested areas

\section{Prättigau, project partner: WSL, Birmensdorf}

\subsection{The expected climate}

Climate Modelling for the case study was carried out by WSL for different climatic parameters and summarized for specific time periods characterizing the past and the future climate according to the IPCC A1B SRES scenario. Comparing the climate scenarios for the case study sub areas indicated almost overall similar trends. Therefore the presentation of climate data was limited to a single set of figures showing precipitation and temperature development assuming representativeness for the case study Oberschwaben / Allgäu/Vorarlberg/Prättigau. 


\subsection{Precipitation}

The development for four 30-year mean time slices of daily precipitation (1971-2000, 2001-2030, 2031-2060 and 2071-2100) is presented in figure 6. Generally overall precipitation seems to decrease up to the end of the century. It can be assumed that summer precipitation will decrease significantly whereas early spring may be slightly wetter than in the past. The availability of water during the vegetation period will decrease.

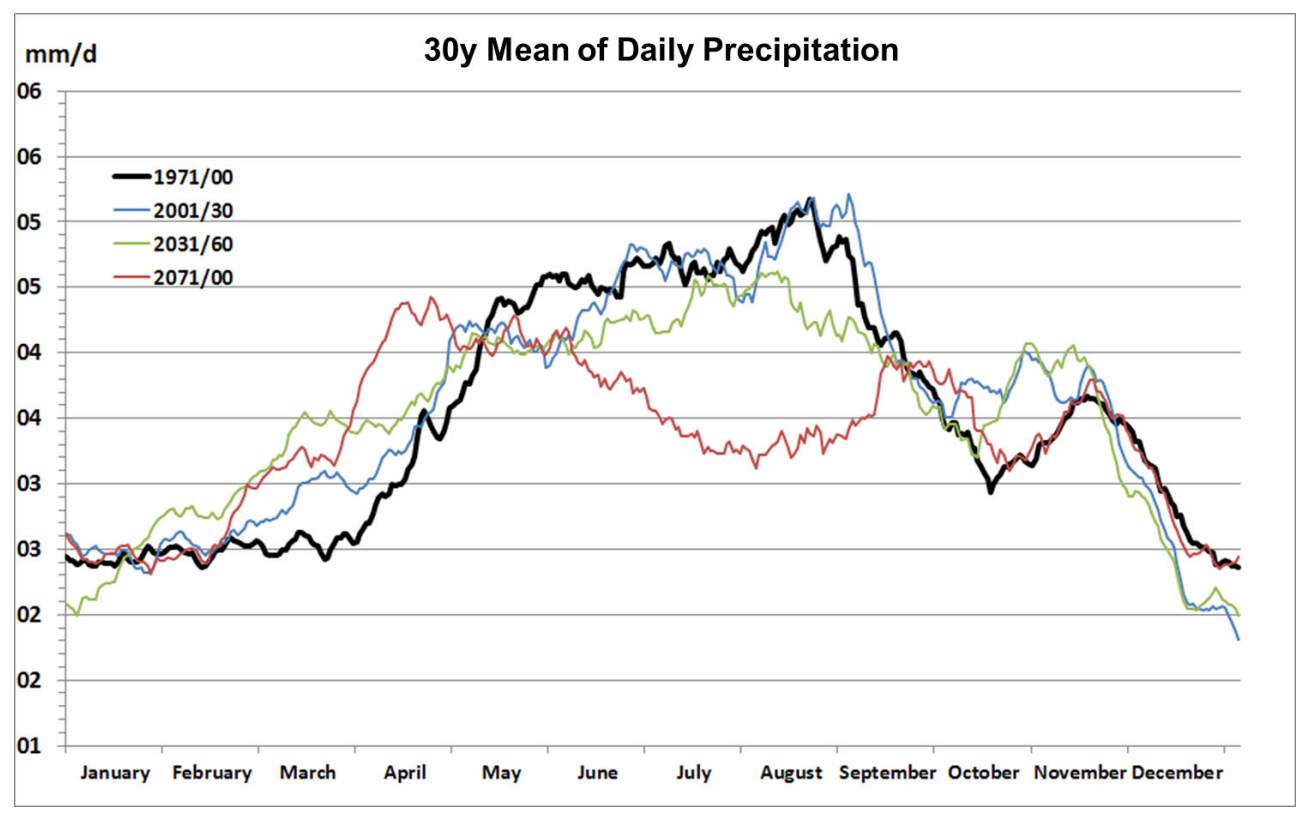

Figure 6. Development of Precipitation (30-year Mean of Daily Sum)

The modelling results presented in figure 6 are in line with the data presented in figure 7 . Up to the first half of this century there will be hardly any change in the number of dry days in the vegetation period. This will change dramatically as the region will face $30 \%$ increase of dry days until 2100 favouring drought tolerant tree species.

\subsection{Temperature}

According to the A1B climate scenario of the IPCC there will be a steady temperature increase up to the end of this century (figure 8). Within the second and especially the last third of the modeling period temperatures will increase in all months of the year and stronger than in the periods before. Particularly the summer and winter months seem be subject to these alterations. 


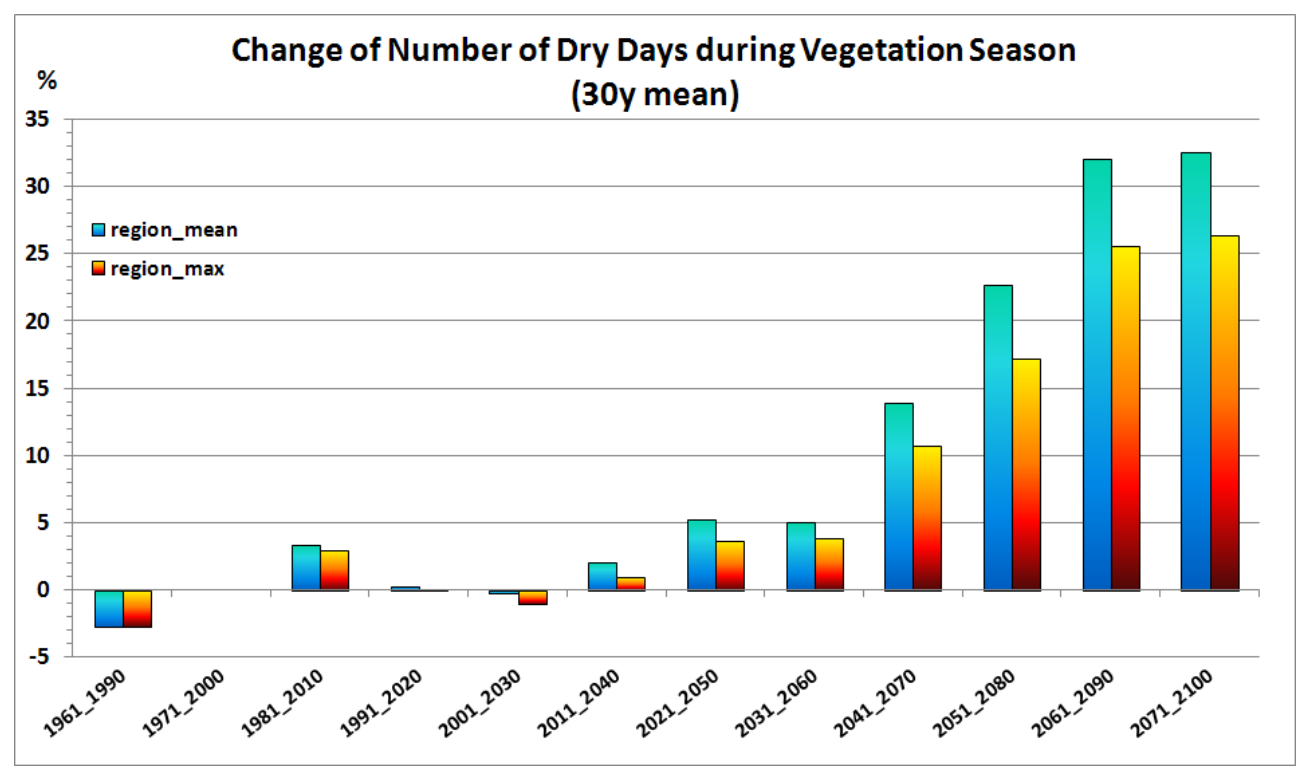

Figure 7. Change of the Number of Dry Days During the Vegetation Period

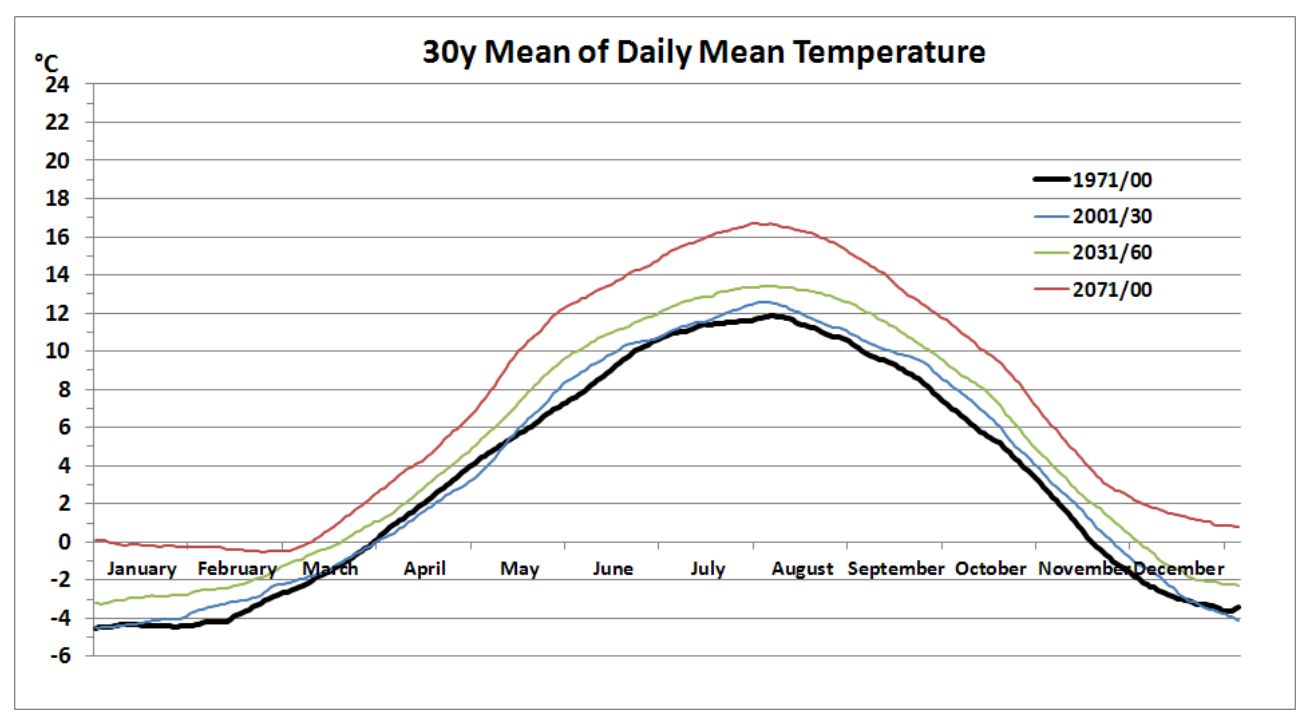

Figure 8. Development of the Daily Mean Temperature 
Also the number of temperature dependant heat waves (figure 9) will more than double in the course of the present century becoming more and more noticeable from mid-century on.

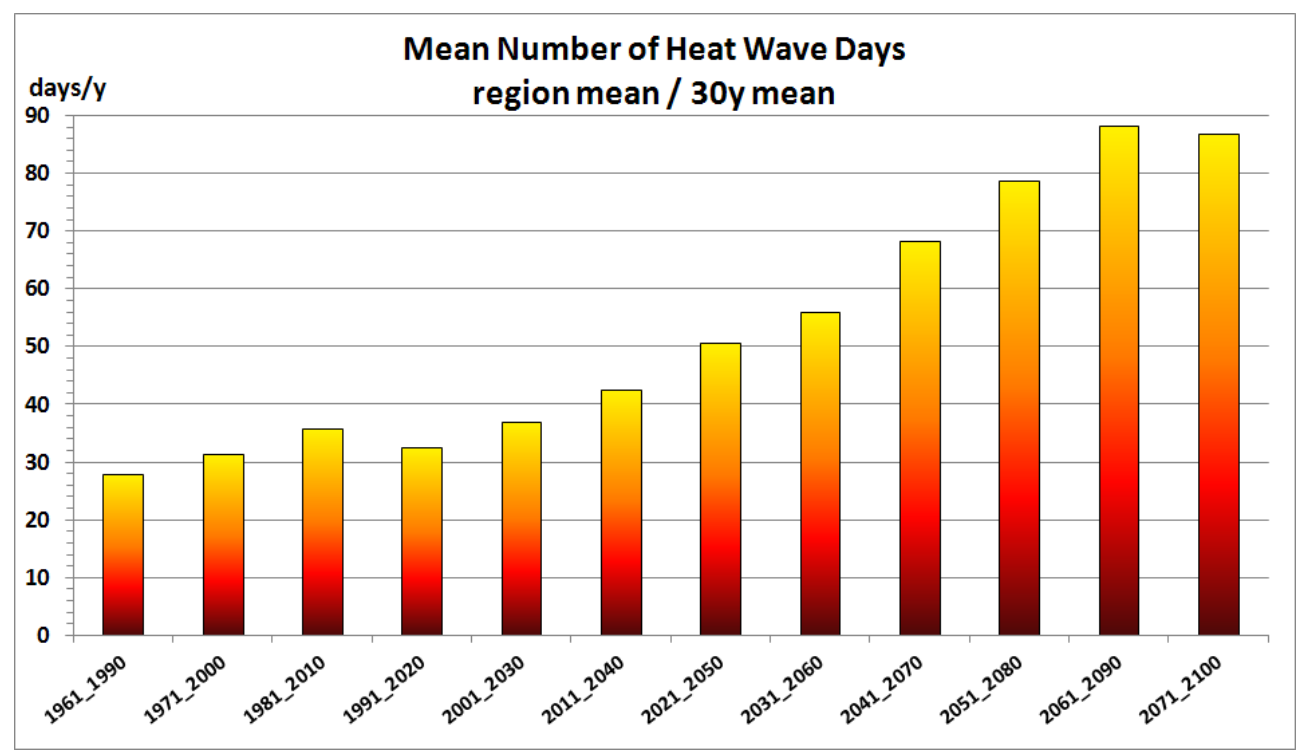

Figure 9. Maximum Length of Heat Waves

\section{Author details}

Holger Veit ${ }^{1}$, Holger Grieß ${ }^{2}$, Bernhard Maier ${ }^{3}$ and Peter Brang ${ }^{1}$

1 Department of Biometrics, Forest Research Institute of Baden Württemberg, Freiburg, Germany

2 Department of Forest Management, Bavarian Forest Institute, Freising, Germany

3 Stand Montafon - Forstfonds, Schruns, Austria

\section{References}

[1] Schröter H.; Becker T.; Weigerstorfer D.; Veit H. Waldschutzprobleme nach "Lothar". In: Ministerium für Ernährung und Ländlichen Raum Baden-Württemberg (Hrsg.) Orkan "Lothar" - Bewältigung der Sturmschäden in den Wäldern Baden-Württem- 
bergs, Dokumentation, Analyse, Konsequenzen. Schriftenreihe LFV Baden-Württemberg 2004; Bd. 83 341-365.

[2] Dönz-Breuss M., Maier B. \& Malin H. Management for forest biodiversity in Austria - the view of a local forest enterprise. Ecological Bulletin 2004, 51.

[3] Brang P., Schöneberger W., Bachofen H., Zingg A. \& Wehrli A. Schutzwalddynamik unter Störungen und Eingriffen: Auf dem Weg zu einer systemischen Sicht. Forum für Wissen 2004, 55-66.

[4] Brang, P. Resistance and Elasticity: promising concepts for the management of protection forests in the European Alps. Forest Ecology and Management 2001; 145 107-117.

[5] Dorren, L. K. A., Berger, F., Imeson, A.C., Maier, B. \& Rey, F. Integrity, stability and management of protection forests in the European Alps. Forest Ecology and Management 2004; 195(1-2) 165-176.

[6] Schelhaas, M.J., Nabuurs, G.J., Schuck, A. Natural disturbances in the European forests in the 19th and 20th centuries. Global Change Biology 2003; 9 1620-1633.

[7] Schmidt M., Hanewinkel M., Kändler G., Kublin E \& U. Kohnle. An inventory-based approach for modeling single-tree storm damage - experiences with the winter storm of 1999 in south western Germany. Canadian Journal of Forest Research, 2010, 40(8): 1636-1652.

[8] Solomon S., D. Qin, M. Manning, Z. Chen, M. Marquis, K.B. Averyt, M. Tignor and H.L. Miller, editors. Contribution of Working Group I to the Fourth Assessment Report of the Intergovernmental Panel on Climate Change, Summary for Policymakers. New York, USA: Cambridge University Press; 2007.

[9] Coumou D., Rahmstorf S. A Decade of Weather Extremes. Nature Climate Change 2012; DOI: 10.1038/NCLIMATE1452

[10] Hanewinkel M., Breidenbach J., Neeff T., Kublin E. Seventy-seven years of natural disturbances in a mountain forest area - the influence of storm, snow and insect damage analyzed with a long-term time series. Canadian Journal of Forest Research 2008;38 (8) 2249-2261. DOI 10.1139/X08-070*

[11] Schelhaas M-J., Nabuurs G.J. and Schuck A. Natural disturbances in the european forests in the 19th and 20th centuries. Global Change Biology 2003; 9 1620-1633.

[12] Lindner M, Maroschek M, Netherer S, Kremer A, Barbati A, Garcia-Gonzalo J, Seidl R, Delzon S, Corona P, Kolström M, Lexer M J, Marchetti M. Climate change impacts, adaptive caoacity, and vulnerability of European forest ecosystems, Forest Ecology and Management 2010; 259, 698-709. 
[13] Forster B. et. al. Erfahrungen im Umgang mit Buchdrucker-Massenvermehrungen (Ips typographus L.) nach Sturmereignissen in der Schweiz. Schweizerische Zeitschrift für Forstwesen 2003;154 (11) 431-436.

[14] Meier F., Gall R. \& B. Forster: Ursachen und Verlauf der Buchdrucker-Epidemien (Ips typographus L.) in der Schweiz von 1984 bis 1999. Schweizerische Zeitschrift für Forstwesen 2003; 15411 437-441.

[15] Steyrer G., Krehan H. Borkenkäferkalamität 2010: Schäden weiterhin sehr hoch. BFW aktuell 2011; 52 4-5.

[16] Becker T., Schröter H. Ausbreitung von rindenbrütenden Borkenkäfern nach Sturmschäden. Allgemeine Forstzeitung 2000; 55 280-282.

[17] Wermelinger B. Ecology and management of the spruce bark beetle Ips typographus - a review of recent research. Forest Ecology and Management 2004; 202 67-82.

[18] Seidl R., Baier P., Rammer W., Schopf A., Lexer M. J. Modeling tree mortality by bark beetle infestation in Norway spruce forests. Ecological Modeling 2007; 206(3-4) 383-399.

[19] Seidl R., Rammer W., Jäger D., Lexer M. J. Impact of bark beetle (Ips typographus L.) on timber production and carbon sequestration in different management strategies under climate change. Forest Ecology and Management 2008; 256 209-220.

[20] Becker T., Schröter H. Die Ausbreitung des Borkenkäferbefalls im Bereich von Sturmwurf- Sukzessionsflächen. Berichte Freiburger Forstliche Forschung 2001; 2679 S.

[21] Annila E. Influence of temperature upon the development and voltinism of Ips typographus L. (Coleoptera, Scolytidae). Ann. Zool. Fenn. 1969; 6 161-208.

[22] Coeln M. Grundlage für ein thermoenergetisches Modell zur Fernüberwachung der Borkenkäferentwicklung. Dissertation, Institut für Forstentomologie, Forstpathologie und Forstschutz der Universität für Bodenkultur. Wien; 1997.

[23] Baier P.; Pennerstorfer J.; Schopf A. PHENIPS - A comprehensive phenology model of Ips typographus (L.) (Col., Scolytinae) as a tool for hazard rating of bark beetle infestation. Forest Ecology and Management 2007; 249 171-186.

[24] Anandhi A., A. Frei, D. C. Pierson, E. M. Schneiderman, M. S. Zion, D. Lounsbury, and A. H. Matonse. Examination of change factor methodologies for climate change impact assessment, Water Resour. Res. 2011; 47, W03501, DOI 10.1029/2010WR009104.

[25] Wermelinger B., Seifert M. Analysis of the temperature dependent development of the spruce bark beetle Ips typographus (L.) (Col., Scolytidae). Journal of Applied Entomology. 1998; 122(4) 185-191. 
[26] R Development Core Team. R - A Language and Environment for Statistical Computing. http://www.R-project.org (accessed 15 September 2010).

[27] System for Automated Geoscientific Analyses. http://sourceforge.net/projects/sagagis/files/SAGA\%20-\%202.0/SAGA\%202.0.4/ (Accessed 15 August 2010).

[28] Lobinger G. Die Lufttemperatur als limitierender Faktor für die Schwärmaktivität zweier rindenbrütender Fichtenborkenkäferarten, Ips typographus L. und Pityogenes chalcographus L. (Col. Scolytidae). Anzeiger für Schädlingskunde, Pflanzenschutz, Umweltschutz 1994; 67 14-17.

[29] Doležal P, Sehnal F. Effects of photoperiod and temperature on the development and diapause of the bark beetle Ips typographus. Journal of Applied Entomology 2007; 131 165-173.

[30] Schröter H., Delb H., Metzler B. Die Waldschutzsituation 2003/2004 in Baden-Württemberg. AFZ/Der Wald 2004; 59 343-345.

[31] Führer E., Nopp U. Ursachen, Vorbeugung und Sanierung von Waldschäden. Wien: Facultas-Universitätsverlag; 2001.

[32] Hanewinkel M., Hummel S., Cullmann D. A. Modeling and economic evaluation of forest biome shifts under climate change in Southwest Germany. Forest Ecology and Management 2010; 259 710-719. 